\title{
Association between Estrogen, Vitamin D and Microrna 17 Gene Polymorphisms and Periapical Lesions
}

\author{
Alice Corrêa Silva-Sousa ${ }^{1}{ }^{\circledR}$, Jardel Francisco Mazzi-Chaves ${ }^{2}{ }^{\circledR}$, Jessica \\ Vavassori Freitas ${ }^{3(}{ }^{\circledR}$, Alessandro Guimarães Salles ${ }^{4}$, Raquel Assed Bezerra \\ da Silva Segato ${ }^{5}$, Léa Assed Bezerra da Silva ${ }^{5}{ }^{\circledR}$, Livia Azeredo Alves \\ Antunes $^{4 \odot}$, Leonardo Santos Antunes ${ }^{4 \odot}$, Flares Baratto-Filho ${ }^{3 \oplus}$, Manoel \\ Damião Sousa-Neto ${ }^{2}$, Erika Calvano Küchler ${ }^{3,5}$ (])
}

This study evaluated the association between polymorphisms in genes encoding estrogen receptors 1 (ESR1) and 2 (ESR2), vitamin D receptor (VDR) and in microRNA17 (which binds to ESR1 and VDR) with persistent apical periodontitis (PAP) after the endodontic treatment. We included 162 patients who completed endodontic treatment at least one year ago and presented apical periodontitis at the beginning of the root canal therapy. Clinical and radiographic exams were performed to evaluate the presence of PAP or healthy periradicular tissues (healed). Saliva samples were collected as a genomic DNA. The genotyping of ESR1 (rs2234693 and rs9340799), ESR2 (rs1256049 and rs4986938), VDR (rs739837 and rs2228570) and miRNA17 (rs4284505) were performed by real-time PCR. Chi-square test was used to the distribution of genotype and allele frequencies. Haplotype analysis was also performed. Eighty-nine patients were included in the "healed" group and 73 in the "PAP" group. No association was found between the allelic and genotypic polymorphisms studied and PAP ( $p>0.05)$. Haplotype analysis also did not demonstrated an association ( $p>0.05$ ). In conclusion, the genetic polymorphisms in ESR1, ESR2, VDR and miRNA17 are not associated with PAP.
'School of Dentistry,UNAERP Universidade de Ribeirão Preto, Ribeirão Preto, SP, Brazil ${ }^{2}$ Department of Restorative Dentistry, School of Dentistry of Ribeirão Preto, USP- Universidade de São Paulo, Ribeirão Preto, SP, Brazil ${ }^{3}$ School of Health Sciences, Graduate Program in Dentistry, UP - Universidade Positivo, Curitiba, PR, Brazil ${ }^{4}$ Department of Specific Formation, School of Dentistry of Nova Friburgo, UFF - Universidade Federal Fluminense, Nova Friburgo, RJ, Brazil ${ }^{5}$ Department of Pediatric Dentistry, School of Dentistry of Ribeirão Preto, USP - Universidade de São Paulo, Ribeirão Preto, SP, Brazil

Correspondence: Jardel Francisco Mazzi-Chaves, Av. Do Café, s/n, 14048-904 Ribeirão Preto, SP, Brasil. Tel: +55-16-3315-3982. e-mail: jardel.chaves@usp.br

\begin{abstract}
Key Words: persistent apical periodontitis, genetic polymorphisms, vitamin $d$, estrogen
\end{abstract}

\section{Introduction}

The apical periodontitis (AP) is an inflammatory and infection condition that results from a host reaction of anaerobic polymicrobial infection of the root canal system, which leads to necrosis of the pulp tissue (13). This inflammatory reaction causes destruction of periradicular tissues, which can be observed in periapical radiographs as radiolucent areas confined to the root apex (1-4). The complete healing of the apical periodontitis and the restoration of the function are the fundamental goals of non-surgical root canal therapy (5). However, the persistent apical periodontitis (PAP) after satisfactory root canal therapy may occur (6), and many studies have been demonstrating that genetic polymorphisms are involved in the PAP (3,7-13). Genetic polymorphisms can be defined as differences in the human DNA sequence, in more than $1 \%$ of the population, which influence the organism's susceptibility to disease and its responses to the environment (3,5-13).

Estrogen presents multifunctional in many tissues, mainly in bone. Estrogen in bone metabolism plays an important role in RANKL (Receptor activator of NF-
kB ligand) and OPG (osteoprotegerin) release (14) and in bone-regulating cytokines IL1 (interleukin 1), IL6 (interleukin 6), TNF-alpha (tumor necrosis factor), and prostaglandin-E2. These factors increase bone resorption and are downregulated by estrogen (15). Studies performed in estrogen deficiency rats with experimental apical periodontitis showed that they have a significantly increased bone loss (16-18). Estrogen binds to either $E R \alpha$ (estrogen receptor alpha) or ER $\beta$ (estrogen receptor beta) stimulating ER-positive cell lines (19). The genes ESR1 and ESR2 encode ER $\alpha$ and ER $\beta$ (20).

In addition, vitamin $D$ is an important factor in estrogen biosynthesis of both women and men (21). It is worth mentioning that vitamin $D$ is essential in bone formation and remodeling. The molecular mechanisms of the vitamin D system contribute to the maintenance of plasma calcium, phosphate and bone mineral homeostasis $(22,23)$. Vitamin $D$ receptor, which is encoded by VDR gene, is recognized as a member of the super-family of nuclear receptors that regulate genes expression and has a central role in the biology of vitamin D action (24). The VDR expression contribute to the maintenance of plasma calcium, 
phosphate and bone mineral homeostasis $(22,23)$. VDR is expressed by all three major bone cell types: osteoblasts, osteoclasts, and osteocytes. The ablation of the VDR gene produces hereditary vitamin-D-resistant rickets, alopecia, hypocalcaemia, hypophosphatemia, and rickets. This condition has been associated with bone loss and cortical bone porosity severe enough to initiate spontaneous bone fractures, showing that any defect in bone mineralization is largely dependent on the availability of plasma calcium and phosphate via VDR-mediated tissue absorption $(22,23)$. Interestingly, a common oral manifestation in patients with vitamin D-resistant rickets is apical periodontitis (25).

MicroRNAs (miRNAs) are a family of small non-coding RNAs that regulate genes expression post-transcriptionally. The miRNAs can affect the stability and degradation of specific target mRNAs and, consequently, causing translational inhibition (26). miRNAs are important in the differentiation and proliferation of bone cells and is also pointed as potential novel diagnostic biomarkers for bone diseases and bone regeneration (27).

Although ERs, VDR and miRNAs have been widely studied in bone diseases, their role in apical periodontitis is still largely unknown. Therefore, the aim of this study $\Xi$ was to evaluate if genetic polymorphisms in ESR1, ESR2, VDR and miRNA17 are associated with PAP.

\section{Material and Methods}

Sample Description

The protocol for this study was approved by the Research Ethics Committee of the University of São Paulo, Ribeirão Preto, São Paulo, Brazil (2.323.266) and by the Research Ethics Committee of the Fluminense Federal University, Rio de Janeiro, Brazil (1.029.674). Informed written consent was obtained with an assent document by all subjects.

A sample of 162 (117 females and 45 males) patients were evaluated in the present study. The recruitment of the subjects was previously described in Mazzi-Chaves et al (3) and in Petean et al (13). Only subjects with pulp necrosis associated with apical periodontitis at the beginning of the root canal therapy and those that attended regular follow-up visit were selected. This selection was based in previous studies $(3,7,8,13)$. Patients with at least one root canal-treated in any permanent human teeth, no obvious reason for root canal failure. Clinical information regarding their general health, systemic desease, smoking and parafunctional habits was collected through an anamnesis from all subjects.

\section{Phenotype Determination}

During the regular follow-up appointments, the phenotype was determined based on the periapical radiographs and clinical aspects. Immediate postoperative radiographs were compared with the recall radiographs after at least 1 year of the end of endodontic treatment, by the same calibrate observer as described in Petean et al. (13).

The treatment outcome was categorized in PAP and healed, according to Morsani et al. (7), in which PAP was defined as follow: a lack of healing with apparently well obturated root canal system(s) as determined by a radiographic examination; root canal therapy completed at least a year prior with signs and symptoms of the condition; the preexisting radiographic lesion persists; and the presence of a clinical signs or symptoms of periapical conditions, such as sinus tract, pain and swelling. Healed was considered as follow: the absence of pain and swelling; disappearance of the sinus tract; no loss of function and no evidence of tissue destruction.

\section{Mirna and Polymorphisms Selection}

The genetic polymorphisms in ESR1 (rs2234693 and rs9340799), ESR2 (rs1256049 and rs4986938) and VDR (rs739837 and rs2228570) genes were selected based on their function in bone biology (28-30) and in their minor allele frequencies, that should be higher than $10 \%$.

The selection of the miRNA was performed through the miRanda software (31), which was used to scan miRNAmRNA interactions. This software uses a target prediction algorithms and identified the miRNA17 as targets the mRNA of both genes, ESR1 and VDR, with high scores of predicted alignment (www.mirna.org). The genetic polymorphism rs4284505 in miRNA17 was selected due the fact that it was the only polymorphism which a minor allele frequency higher than $10 \%$.

The characteristics of the selected genes and polymorphisms are presented in the Table 1.

\section{DNA Extraction and Genotyping Analysis}

Saliva samples were collected from all included subjects. Genomic DNA for the allelic discrimination analysis was extracted from buccal cells isolated from saliva as described in Mazzi-Chaves et al. (3) and Petean et al. (13).

Genotyping was performed by real-time polymerase chain reactions (PCR) using the TaqMan assay in the realtime PCR system ABI PRISM ${ }^{\circledR} 7500 \mathrm{HT}$ (Foster City, CA, USA). The probes and the master mix are from Applied Biosystems (Foster City, CA, USA).

\section{Statistical Analysis}

Data were analyzed using Plink. Age differences between groups were calculated using t-test. Fisher's exact and Pearson chi-square tests were used to compare the demographic difference (age, sex, ethnicity, healthy condition and habits) between groups. Pearson chi-square test was used to compare genotypes distributions between 
'Healed' and 'PAP' in the additive, recessive and dominant model and the allele distributions. Haplotype analysis was performed with the polymorphisms rs2234693-rs9340799, rs1256049-rs4986938 and rs739837-rs2228570 in ESR1, ESR2 and VDR respectively.

All tests were performed with an established alpha of
0.05. Hardy-Weinberg equilibrium was evaluated using the chi-square test within each polymorphism in each population set.

\section{Results}

Among the included patients, 89 was included in the "healed" group and 73 in the "PAP" group. The subjects age ranged from 16 to 83 . Age, gender and medical conditions were not associated with PAP ( $p>0.05)$.

All the studied genetic polymorphisms were in Hardy-Weinberg equilibrium (data not shown).

Table 2 demonstrated the genotype distribution of the studied polymorphisms in the healed and PAP groups. There was no association between the studied polymorphisms and PAP in the additive, recessive and dominant models ( $p>0.05$ ).

Alleles frequencies distributions were not associated with PAP ( $p>0.05$ ). Haplotype analysis of rs2234693-rs9340799, rs1256049rs4986938 and rs739837-rs2228570 were not associated with PAP ( $p>0.05)$.

Table 2. Genotype distributions among the groups

\begin{tabular}{|c|c|c|c|c|c|c|c|}
\hline \multirow[b]{2}{*}{ Genes } & \multirow[b]{2}{*}{ Polymorphisms } & \multirow[b]{2}{*}{ Genotypes } & \multicolumn{2}{|c|}{ Groups } & \multicolumn{3}{|c|}{ p-values } \\
\hline & & & $\begin{array}{c}\text { Healed } \\
\mathrm{n}(\%)\end{array}$ & $\begin{array}{l}\text { PAP } \\
\mathrm{n}(\%)\end{array}$ & $\begin{array}{c}\text { Additive } \\
\text { model }\end{array}$ & $\begin{array}{c}\text { Recessive } \\
\text { model }\end{array}$ & $\begin{array}{c}\text { Dominant } \\
\text { model }\end{array}$ \\
\hline \multirow{6}{*}{ ESR1 } & \multirow{3}{*}{ rs2234693 } & $\mathrm{CC}$ & $18(18.0)$ & $16(16.0)$ & \multirow{3}{*}{0.98} & \multirow{3}{*}{0.99} & \multirow{3}{*}{0.85} \\
\hline & & $\mathrm{CT}$ & $36(35.5)$ & $31(31.5)$ & & & \\
\hline & & $\mathrm{TT}$ & $27(27.5)$ & $25(24.5)$ & & & \\
\hline & \multirow{3}{*}{ rs9340799 } & AA & $34(37.2)$ & 35 (31.9) & \multirow{3}{*}{0.50} & \multirow{3}{*}{0.38} & \multirow{3}{*}{0.28} \\
\hline & & AG & $31(29.6)$ & $24(25.4)$ & & & \\
\hline & & GG & $12(10.2)$ & $7(8.7)$ & & & \\
\hline \multirow{5}{*}{ ESR2 } & \multirow{2}{*}{ rs1256049 } & $\mathrm{CC}$ & $72(87.8)$ & $63(0.90)$ & \multirow{2}{*}{0.66} & \multirow{2}{*}{ - } & \multirow[b]{2}{*}{-} \\
\hline & & $\mathrm{CT}$ & $10(12.2)$ & $7(0.10)$ & & & \\
\hline & \multirow{3}{*}{ rs4986938 } & $\mathrm{CC}$ & $43(41.5)$ & $34(35.5)$ & \multirow{3}{*}{0.20} & \multirow{3}{*}{0.07} & \multirow{3}{*}{0.62} \\
\hline & & $\mathrm{CT}$ & $33(30.7)$ & $24(26.3)$ & & & \\
\hline & & $\mathrm{TT}$ & $8(11.8)$ & $14(10.2)$ & & & \\
\hline \multirow{6}{*}{ VDR } & \multirow{3}{*}{ rs739837 } & GG & $18(15.7)$ & $11(13.3)$ & \multirow{3}{*}{0.57} & \multirow{3}{*}{0.61} & \multirow{3}{*}{0.43} \\
\hline & & GT & $38(37.9)$ & $32(32.1)$ & & & \\
\hline & & $\mathrm{TT}$ & $28(30.3)$ & $28(25.6)$ & & & \\
\hline & \multirow{3}{*}{ rs 2228570} & AA & $8(8.31)$ & $7(6.7)$ & \multirow{3}{*}{0.77} & \multirow{3}{*}{0.88} & \multirow{3}{*}{0.52} \\
\hline & & AG & $43(40.9)$ & $31(33.2)$ & & & \\
\hline & & GG & $35(36.9)$ & $32(30.1)$ & & & \\
\hline \multirow{3}{*}{$\begin{array}{l}\text { MiRNA } \\
17\end{array}$} & \multirow{3}{*}{ rs 4284505} & AA & $18(18.5)$ & $15(14.5)$ & & & \\
\hline & & AG & 48 (43.7) & $30(34.3)$ & 0.33 & 0.84 & 0.18 \\
\hline & & GG & $22(25.8)$ & $24(10.2)$ & & & \\
\hline
\end{tabular}

Note: for the polymorphism rs 1256049 the recessive and dominant model were not calculated because none of the individual presented TT genotype.

\section{Discussion}

In the pastyears, studies of the genetic factors associated with oral phenotypes have been emerging (32), including studies that evaluated the association of genetic polymorphisms in the apical periodontitis pathogenesis and phenotype $(3,8-13,33)$. The current evidence supports the concept that PAP is a multifactorial condition, in which many genes play an important role.

In previous study (13), genetic polymorphisms in RANK and RANKL were associated with PAP. Bone processes are controlled mainly by the interaction between RANK, RANKL and OPG $(34,35)$. The balance between RANKL and OPG expression is determinant on the bone remodeling process, and studies in animal model 
$(36,37)$ and humans $(38,39)$ have demonstrating that RANK, RANKL and OPG triad are important in the development, progression and repair of AP. The bone resorption process is mainly controlled by the RANK / RANKL / OPG signaling pathway, which are considered regulators of the bone remodeling process. RANKL is a soluble mediator, synthesized by osteoblasts, bone marrow stromal cells, and endothelial cells. Although there is a physiological expression of RANKL, this is a molecule abundantly produced by T lymphocytes throughout inflammatory processes. In addition, RANKL is the mediator responsible for binding to RANK, a surfaceexpressed receptor of osteoclasts and their progenitors, macrophages present in the bone marrow that after this binding receive the stimulation of maturation and conversion into active osteoclasts. The OPG is a soluble receptor secreted by osteoblast anabolic stimuli through which competes with RANK for binding to RANKL agent, thereby preventing this link, so as to inhibit osteoclast genesis (13,34-39). Therefore, we hypothesize that genetic polymorphisms in genes that encode molecules involved in this triad are candidates to PAP in humans.

Estrogen are involved in the triad RANK, RANKL and OPG $(14,40)$, in which estrogen exert anti-resorptive effects on bone, at least in part, by stimulating ERs and OPG expression in osteoblasts (40). In addition, ER $\alpha$ is involved in the RANKL/ OPG ratio (41). Additionally, the importance of ERs on cortical and trabecular bone, and also in different bone cell

types have been widely explored (42). Although the studied genetic polymorphism rs2234693 and rs9340799 in ESR1 and rs1256049 and rs4986938 were not associated with PAP in the present study, they were previously associated with many different bone conditions $(28,43)$ and oral conditions (43-45). The genetic polymorphisms rs 2234693 and rs9340799 in ESR1 have been largely studied. The evidence linking these polymorphisms and its haplotype to bone mineral density $(28,46)$. Also they were associated with postmenopausal osteoporosis $(28,43)$. According to Rivadeneira et al (47), genetic polymorphisms in ESR2 alone and in interaction with ESR1 can also influence the risk of bone fracture in postmenopausal women.

It is important to emphasize although the studied genetic polymorphisms were not associated with PAP, it is possible that estrogen play an important role in this endodontic phenotype. Estrogen deficiency after ovariectomy or menopause plays an important role in the early alterations in the turnover of cancellous bone, leading to both the early and late forms of osteoporosis in women (48) and in animals with induced apical periodontitis, they presented a larger lesion (16-18). Therefore, it is possible that estrogen deficiency in humans could be involved in the PAP.

Recent data with an osteoblast-specific VDR knockout mouse model demonstrated impaired RANKL expression and activity, confirming the crucial role of VDR in osteoblasts during the regulation of osteoclast genesis (22). The function of VDR has also been examined in osteocytes with an osteocyte-specific VDR deletion mouse model (22) and the data showed that high vitamin D levels in the plasma can act on osteocytes to inhibit bone mineral deposition in addition to stimulating bone resorption increasing RANKL expression by osteoblasts and possibly osteocytes (22). On the other hand, the adequate levels of vitamin $D$ reduced bone RANKL expression and bone resorption, while also slightly prolonging the bone formation period of osteoblast (22). VDR genetic polymorphisms have been associated with bone mineral density $(49,50)$ and in immune function $(51,52)$. Furthermore, genetic polymorphisms in VDR have been associated with oral conditions (53-56). The genetic polymorphism rs731236 was associated with external apical root resorption in orthodontic patients (54). A meta-analysis of 15 studies evaluating the association between and aggressive and chronic periodontal disease genetic polymorphisms in VDR also found that this polymorphism was associated with periodontitis (57). However, in our study, both genetic polymorphisms in VDR were not associated with PAP.

It is also possible that post-transcriptional regulatory factors such as miRNAs are also involved in PAP. In fact, a study performed by Chan et al (58) explored the role of miRNAs in endodontic disease and providing novel insight into the genetic regulation of endodontic periapical pathogenesis. They observed that multiples miRNAs were down or up regulated in the diseased periapical tissues. In our study, a genetic polymorphism in miRNA17 was selected due the fact that it targets the miRNA of two candidate genes: ESR1 and VDR. The polymorphism rs4284505 was not associated with PAP, however, it is possible that other genetic polymorphisms in miRNAs are associated with PAP.

Briefly, more genetic polymorphisms should be investigate, so in a near future, they can provide information to allow a personalized treatment of patients with apical periodontitis.

In conclusion, genetic polymorphisms in ESR1 (rs2234693 and rs9340799), ESR2 (rs1256049 and rs4986938), VDR (rs739837 and rs2228570) and miRNA17 (rs4284505) were not associated with persistent apical periodontitis.

\section{Resumo}

Este estudo avaliou a associação entre polimorfismos em genes que codificam os receptores de estrogênio 1 (ESR1) e 2 (ESR2), receptor de vitamina D (VDR) e no microRNA17 (que se liga à ESR1 e VDR) e a periodontite apical persistente (PAP) após o tratamento endodôntico. Foram incluidos 162 pacientes com tratamento endodôntico concluido há pelo menos um ano e que apresentavam periodontite apical no início 
da terapia endodôntica. Exames clínicos e radiográficos foram realizados para avaliar a presença de PAP ou tecidos perirradiculares saudáveis (cicatrizados). As amostras de saliva foram coletadas como fonte de DNA genômico. A genotipagem de ESR1 (rs2234693 e rs9340799), ESR2 (rs1256049 e rs4986938), VDR (rs739837 e rs2228570) e miRNA17 (rs4284505) foram realizadas por PCR em tempo real. 0 teste do quiquadrado foi utilizado para a distribuição das frequências genotípicas e alélicas. A análise de haplótipos também foi realizada. Oitenta e nove pacientes foram incluidos no grupo "curado" e 73 no grupo "PAP". Não foi encontrada associação entre os polimorfismos alélicos e genotípicos estudados e a PAP $(p>0,05)$. Conclui-se que os polimorfismos genéticos em ESR1, ESR2, VDR e miRNA17 não estão associados à PAP.

\section{Acknowledegments}

This work was supported by the São Paulo Research Foundation (FAPESP) (funding number: 2015/06866-5) and individual scholarships (FAPESP and CAPES).

\section{References}

1. Sjögren U, Figdor D, Persson S, Sundqvist G. Influence of infection at the time of root filling on the outcome of endodontic treatment of teeth with apical periodontitis. Int Endod J 1997;30:297-306.

2. Siqueira JF, Rôças IN. Diversity of endodontic microbiota revisited. J Dent Res 2009;88;969-981.

3. Mazzi-Chaves JF, Petean IBF, Soares, IMV, Salles AG, Antunes LAA, Segato RAB et al. Influence Of Genetic Polymorphisms In Genes Of Bone Remodeling And Angiogenesis Process In The Apical Periodontitis. Braz Dent J 2018;29:179-183.

4. Nair PN. On the causes of persistent apical periodontitis: a review. Int Endod J 2006;39:249-281.

5. Aminoshariae A, Kulild JC. Association of Functional Gene Polymorphism with Apical Periodontitis. J Endod 2015;41:999-1007.

6. Chugal N, Mallya SM, Kahler B, Lin LM. Endodontic Treatment Outcomes. Dent Clin North Am 2017;61:59-80.

7. Morsani JM, Aminoshariae A, Han YW, Montagnese TA, Mickel A. Genetic predisposition to persistent apical periodontitis. J Endod 2011;37:455-59.

8. Rôças IN, Siqueira JF Jr, Del Aguila CA, Provenzano JC, Guilherme BP, Gonçalves LS. Polymorphism of the CD14 and TLR4 genes and posttreatment apical periodontitis. J Endod 2014;40:168-172.

9. Evrosimovska B, Dimova C, Popovska L, Zabokova-Bilbilova E. Matrix Matalloproteinase-8 Gene Polymorphism in Chronic Periapical Lesions. Pril 2015;36:217-224.

10. Maheshwari K, Silva RM, Guajardo-Morales L, Garlet GP, Vieira AR, Letra A. Heat Shock 70 Protein Genes and Genetic Susceptibility to Apical Periodontitis. J Endod 2016;42:1467-1471.

11. Trombone APF, Cavalla $F$, Silveira EMV, Andreo $C B$, Francisconi $\mathrm{CF}_{\text {, }}$ Fonseca $A C$, et al. MMP1-1607 polymorphism increases the risk for periapical lesion development through the upregulation MMP-1 expression in association with pro-inflammatory milieu elements. J Appl Oral Sci 2016;24:366-375.

12. Salles AG, Antunes LAA, Küchler EC, Antunes LS. Association between Apical Periodontitis and Interleukin Gene Polymorphismis: A Systematic Review and Meta-analysis. J Endod 2018;44:355-362.

13. Petean IBF, Küchler EC, Soares IMV, Segato RAB, Silva LABD, Antunes $L A A$, et al. Genetic polymorphisms in regulators of bone remodelling genes are associated with persistent apical periodontitis. J Endod 2019;45:526-531

14. Hofbauer LC, Kühne CA, Viereck V. The OPG/RANKL/RANK system in metabolic bone disease. J Musculoskelet Neuronal Interact 2004;4:268275.

15. Manolagas SC. Birth and death of bone cells: basic regulatory mechanisms and implications for the pathogenesis and treatment of osteoporosis. Endocrine Reviews 2000;21:115-137.

16. Brasil SC, Santos RM, Fernandes A, Alves FR, Pires FR, Siqueira JF Jr, et al. Influence of estrogen deficiency on the development of apical periodontitis. Int Endod J 2017:50:161-166.

17. Romualdo $\mathrm{PC}$, Cunha NBFF, Leoni GB, Sousa-Neto MD, Consolaro A, de Queiroz AM et al. The effect of ovariectomy and 2 antiresorptive therapeutic agents on bone response in rats: A 3-dimensional imaging analysis. Oral Surg Oral Med Oral Pathol Oral Radiol Endod 2018;126:218-225.

18. Romualdo $P C$, Lucisano MP, Paula-Silva FWG, Leoni GB, Sousa-Neto $M D$, Silva $R A B$, et al. Ovariectomy exacerbates apical periodontitis in rats with an increase in expression of proinflammatory cytokines and matrix metalloproteinases. J Endod 2018;44:780-785.

19. Klinge $C M$, Jernigan $S C$, Mattingly KA, Risinger KE, Zhang J. Estrogen response element-dependent regulation of transcriptional activation of estrogen receptors alpha and beta by coactivators and corepressors. $\mathrm{J}$ Mol Endocrinol 2004;33:387-410.

20. Enmark E1, Pelto-Huikko M, Grandien K, Lagercrantz $S$, Lagercrantz J, Fried $G$, et al. Human estrogen receptor beta-gene structure, chromosomal localization, and expression pattern. J Clin Endocrinol Metab 1997;82:4258-4265.

21. Kinuta $K$, Tanaka H, Moriwake T, Aya K, Kato S, Seino Y. Vitamin D is an important factor in estrogen biosynthesis of both female and male gonads. Endocrinology 2000;141:1317-1324.

22. Morris HA. Vitamin D activities for health outcomes. Ann Lab Med 2014;34:181-186.

23. Suzuki T, Nakamura Y, Kato H. Calcium and vitamin D supplementation with 3-years denosumab treatment is beneficial to enhance bone mineral density in postmenopausal patients with osteoporosis and rheumatoid arthritis. Ther Clin Risk Manag 2018;15:15-22.

24. Haussler MR, Whitfield GK, Haussler CA, Hsieh JC, Thompson PD, Selznick SH, et al. The nuclear vitamin $D$ receptor: biological and molecular regulatory properties revealed. J Bone Miner Res 1998;13:325-349.

25. Souza AP, Kobayashi TY, Lourenço Neto N, Silva SM, Machado MA, Oliveira TM. Dental manifestations of patient with vitamin D-resistant rickets. J Appl Oral Sci 2013;21:601-616.

26. Cai $\mathrm{C}$, Hagedorn $\mathrm{CH}$, Cullen BR. Human microRNAs are processed from capped, polyadenylated transcripts that can also function as mRNAs. RNA 2004;10:1957-1966

27. Nakasa T, Yoshizuka M, Andry Usman M, Elbadry Mahmoud E, Ochi M. MicroRNAs and Bone Regeneration. Curr Genomics 2015;16,441-452.

28. Mondockova $V$, Adamkovicova $M$, Lukacova $M$, Grosskopf B, Babosova $R$, Galbavy $D$, et al. The estrogen receptor 1 gene affects bone mineral density and osteoporosis treatment efficiency in Slovak postmenopausal women. BMC Med Genet 2018;19:174.

29. Hidalgo-Bravo A, Parra-Torres AY, Casas-Avila L, Jimenez-Ortega RF, Ramírez-Salazar EG, Patiño N, et al. Association of RMND1/ CCDC170-ESR1 single nucleotide polymorphisms with hip fracture and osteoporosis in postmenopausal women. Climacteric 2019;2:1-8.

30. Zimmermann A, Popp RA, Rossmann H, Bucerzan S, Nascu I, Leucuta D. Gene variants of osteoprotegerin, estrogen-, calcitonin- and vitamin D-receptor genes and serum markers of bone metabolism in patients with gaucher disease type 1. Ther Clin Risk Manag 2018;14:2069-2080.

31. Betel D, Koppal A, Agius P, Sander C, Leslie C. mirSVR predicted target site scoring method: Comprehensive modeling of microRNA targets predicts functional non-conserved and non-canonical sites. Genome Biol 2010;11:R90.

32. Küchler EC, Mazzi-Chaves JF, Antunes LS, Kirschneck C, Baratto-Filho $F$, Sousa-Neto MD. Current trends of genetics in apical periodontitis research. Braz Oral Res 2018;32:126-132.

33. Menezes-Silva R, Khaliq S, Deeley K, Letra A, Vieira AR. Genetic susceptibility to periapical disease: conditional contribution of MMP2 and MMP3 genes to the development of periapical lesions and healing response. J Endod 2012;38:604-607.

34. Boyle WJ, Simonet WS, Lacey DL. Osteoclast differentiation and activation. Nature 2003;423:337-342.

35. Boyce BF, Xing L. Functions of RANKL/RANK/OPG in bone modeling and remodeling. Arch Biochem Biophys 2008;473:139-146.

36. Arnez MFM, Ribeiro LSN, Barreto GD, Monteiro PM, Ervolino E, Stuani MBS. RANK/RANKL/OPG expression in rapid maxillary expansion. Braz Dent J 2017;28:296-300. 
37. Barreiros D, Pucinelli CM, Oliveira KMH, Paula-Silva FWG, Nelson Filho $P$, Silva LABD, et al. Immunohistochemical and mRNA expression of RANK, RANKL, OPG, TLR2 and MyD88 during apical periodontitis progression in mice. J Appl Oral Sci 2018;10:26:e20170512.

38. Shang M, Lin L, Cui H. Association of genetic polymorphisms of RANK, RANKL and OPG with bone mineral density in Chinese peri- and postmenopausal women. Clin Biochem 2013;46:1493-1501.

39. Carneiro $E$, Parolin AB, Wichnieski C, Rosa EA, Silva Neto UX, Westphalen VP, et al. Expression levels of the receptor activator of NFkappaB ligand and osteoprotegerin and the number of gram-negative bacteria in symptomatic and asymptomatic periapical lesions. Arch Oral Biol 2017;73:166-171.

40. Bord S, Ireland DC, Beavan SR, Compston JE. The effects of estrogen on osteoprotegerin, RANKL, and estrogen receptor expression in human osteoblasts. Bone 2003;32:136-141.

41. Lindberg MK, Erlandsson M, Alatalo SL, WindahI S, Andersson G, Halleen $J M$, et al. Estrogen receptor alpha, but not estrogen receptor beta, is involved in the regulation of the OPG/RANKL (osteoprotegerin/receptor activator of NF-kappa B ligand) ratio and serum interleukin-6 in male mice. J Endocrinol 2001;171:425-433.

42. Khalid $A B$, Krum $S A$. Estrogen receptors alpha and beta in bone. Bone 2016;87:130-135.

43. Shang DP, Lian HY, Fu DP, Wu J, Hou SS, Lu JM. Relationship between estrogen receptor 1 gene polymorphisms and postmenopausal osteoporosis of the spine in Chinese women. Genet Mol Res 2016;15:16.

44. Arid J, Oliveira DB, Evangelista SS, Vasconcelos KRF, Dutra ALT, de Oliveira SS et al. Oestrogen receptor alpha, growth hormone receptor, and developmental defect of enamel. Int J Paediatr Dent 2019;29:2935.

45. Dalledone $M$, Cunha AS, Ramazzotto LA, Pecharki GD, Nelson-Filho $\mathrm{P}$, Scariot $\mathrm{R}$ et al. Estrogen receptor gene is associated with dental fluorosis in Brazilian children. Clin Oral Investig 2019;23:3565-3570.

46. Rojano-Mejía D, Coral-Vázquez RM, Coronel A, Cortes-Espinosa L, del Carmen Aguirre-Garcia M, Valencia-Villalvazo EY, et al. Relation of the estrogen receptor and vitamin $D$ receptor polymorphisms with bone mineral density in postmenopausal Mexican-mestizo women. Gene 2014;537:10-14.

47. Rivadeneira F, van Meurs JB, Kant J, Zillikens MC, Stolk L, Beck TJ, et al. Estrogen receptor beta (ESR2) polymorphisms in interaction with estrogen receptor alpha (ESR1) and insulin-like growth factor I (IGF1) variants influence the risk of fracture in postmenopausal women. J Bone Miner Res 2006;21:1443-1456.

48. Riggs $\mathrm{BL}$, Khosla $\mathrm{S}$, Melton $\mathrm{U}$. A unitary model for involutional osteoporosis: estrogen deficiency causes both type I and type II osteoporosis in postmenopausal women and contributes to bone loss in aging men. J Bone Miner Res 1998;13:163-173.

49. Uitterlinden $A G$, Fang $Y$, Van Meurs JB, Pols HA, Van Leeuwen JP. Genetics and biology of vitamin D receptor polymorphisms. Gene 2004;338:143-156.

50. Uitterlinden $A G$, Ralston SH, Brandi ML, Carey AH, Grinberg D, Langdahl $\mathrm{BL}$, et al. The association between common vitamin $\mathrm{D}$ receptor gene variations and osteoporosis: a participant-level meta-analysis. Ann Intern Med 2006;145:255-264.

51. García D, Angel B, Carrasco E, Albala C, Santos JL, Pérez-Bravo F. VDR polymorphisms influence the immune response in type 1 diabetic children from Santiago, Chile. Diabetes Res Clin Pract 2007;77:134140.

52. van Etten E, Verlinden L, Giulietti A, Ramos-Lopez E, Branisteanu DD, Ferreira $\mathrm{GB}$, et al. The vitamin $\mathrm{D}$ receptor gene Fokl polymorphism: functional impact on the immune system. Eur J Immunol 2007;37:395405.

53. Inagaki K, Krall EA, Fleet JC, Garcia RI. Vitamin D receptor alleles, periodontal disease progression, and tooth loss in the VA dental longitudinal study. J Periodontol 2003;74:161-167.

54. Fontana ML, de Souza CM, Bernardino JF, Hoette F, Hoette ML, Thum $\mathrm{L}$, et al. Association analysis of clinical aspects and vitamin $\mathrm{D}$ receptor gene polymorphism with externalapical root resorption in orthodontic patients. Am J Orthod Dentofacial Orthop 2012;142:339-347.

55. Zhang X, Rahemtulla F, Zhang P, Beck P, Thomas HF. Different enamel and dentin mineralization observed in VDR deficient mouse model. Arch Oral Biol 2009;54:299-305.

56. Schroth RJ, Rabbani R, Loewen G, Moffatt ME. Vitamin D and Dental Caries in Children. J Dent Res 2016;95:173-179.

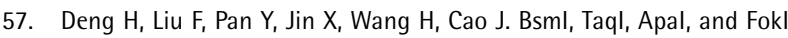
polymorphisms in the vitamin $\mathrm{D}$ receptor gene and periodontitis: a meta-analysis of 15 studies including 1338 cases and 1302 controls. J Clin Periodontol 2011;38:199-207.

58. Chan LT, Zhong S, Naqvi AR, Self-Fordham J, Nares S, Bair E, et al. MicroRNAs: new insights into the pathogenesis of endodontic periapical disease. J Endod 2013;39:1498-1503.

Received October 19, 2019 Accepted December 21, 2019 